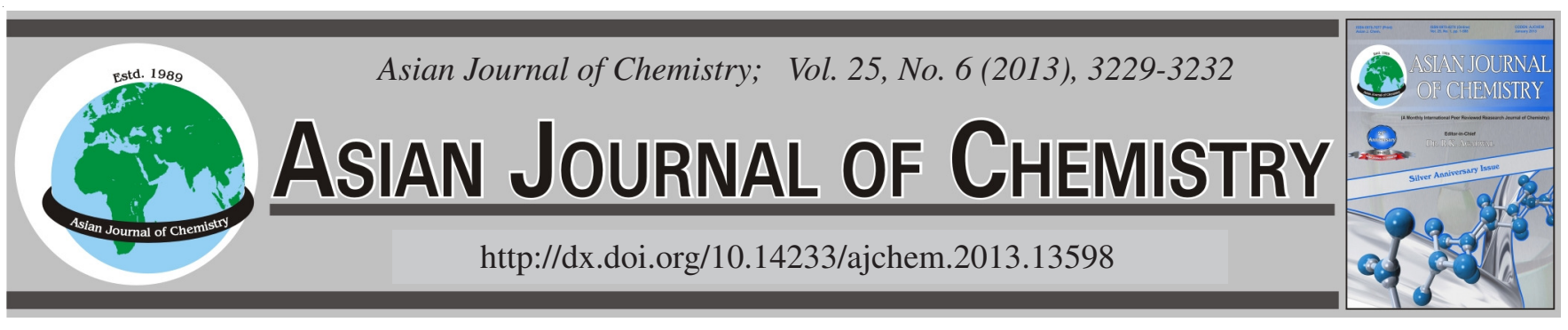

\title{
Lead Content and Isotope Composition in Surface Sediments in Western Xiamen Bay and Its Vicinity: Implication for Possible Source
}

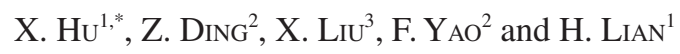

${ }^{1}$ State Laboratory of Analytical Chemistry for Life Science, Center of Material Analysis and School of Chemistry \& Chemical Engineering, Nanjing University, Nanjing 210093, Jiangsu, P.R. China

${ }^{2}$ School of Environment, Nanjing University of Technology, Nanjing 210009, Jiangsu, P.R. China

${ }^{3}$ College of Environment and Ecology, Xiamen University, Xiamen 361005, Fujian, P.R. China

*Corresponding author: Fax: +86 25 83325180; Tel: +86 25 83592247; E-mail: huxin@nju.edu.cn

\begin{abstract}
Lead contents and isotope compositions $\left({ }^{206} \mathrm{~Pb} /{ }^{207} \mathrm{~Pb}\right.$ and $\left.{ }^{208} \mathrm{~Pb} /{ }^{206} \mathrm{~Pb}\right)$ in surface sediments in western Xiamen Bay and its vicinity in South Fujian, China, were measured to assess the spatial variations and to identify $\mathrm{Pb}$ sources. The spatial variations of $\mathrm{Pb}$ contents in sediments were confirmed and enrichment factors suggested deficiency to minimal enrichment of anthropogenic lead in sediments. Lead isotopic ratios ranged from 1.173-1.186 with the mean value of 1.181 for ${ }^{206} \mathrm{~Pb} /{ }^{207} \mathrm{~Pb}$ and from $2.078-2.101$ with the mean value of $2.094 \mathrm{for}{ }^{208} \mathrm{~Pb} /$ ${ }^{206} \mathrm{~Pb}$, respectively. The $\mathrm{Pb}$ isotope ratios indicated the homogenization of isotope compositions and confirmed that vehicular $\mathrm{Pb}$ was not the primary $\mathrm{Pb}$ contamination sources in the sediments in the studied region. Chinese coal and Fujian $\mathrm{Pb}-\mathrm{Zn}$ deposits might be the potential anthropogenic $\mathrm{Pb}$ sources and Fujian basalts and granite are the important natural $\mathrm{Pb}$ source.
\end{abstract}

Key Words: Sediment, $\mathrm{Pb}$ content, $\mathrm{Pb}$ isotope composition, Source identification.

\section{INTRODUCTION}

Lead is used widely in many industrial processes and occurs as an important contaminant in all environmental compartments (soils, water, the atmosphere, sediments and living organisms). Lead contamination may result both from its persistence and from its present and past numerous sources such as smelting, combustion of leaded gasoline, or applications of lead-contaminated media. In 2009, production of recoverable lead from mining operations was 1690, 516 and 400 thousand metric tons by China, Australia and the USA, respectively ${ }^{1}$. Lead has four stable isotopes: ${ }^{204} \mathrm{~Pb},{ }^{206} \mathrm{~Pb},{ }^{207} \mathrm{~Pb}$ and ${ }^{208} \mathrm{~Pb}$, the last three with radiogenic origins from ${ }^{238} \mathrm{U},{ }^{235} \mathrm{U}$ and ${ }^{232} \mathrm{Th}$, respectively ${ }^{2-4}$. Since each source of $\mathrm{Pb}$ can have a distinct or sometimes overlapping isotopic ratio range and physico-chemical fractionation processes do not alter the $\mathrm{Pb}$ isotopic composition of $\mathrm{Pb}$ sources, therefore the use of the lead isotope ratio is referred to as "lead fingerprinting ${ }^{12-4}$. Lead concentration and isotopes have been widely used to trace environmental $\mathrm{Pb}$ pollution and to identify the $\mathrm{Pb}$ sources $^{2-4}$. Lead isotope signatures have been successfully used on the sediment investigations to trace or identify the lead sources ${ }^{4-7}$.

Western Xiamen Bay located in South Fujian, China, is a semi-enclosed bay and is adjacent to Jiulong River Estuary. The rapid development of the Xiamen Special Economic Zone set up in 1980s has resulted in great environmental stresses around western Xiamen Bay and its adjacent areas. Some researches on sediment investigations show a serious situation with $\mathrm{As}, \mathrm{Pb}$ and $\mathrm{Zn}$ and those may have ecological risks ${ }^{8-10}$. In the present study, surface sediments and suspended particle matters were collected from western Xiamen Bay and the Jiulong River Estuary. Lead contents and isotopic ratios were analyzed. The purpose of this study is to assess the spatial variations and to identify the metal sources for the surface sediment from western Xiamen Bay and its vicinity using $\mathrm{Pb}$ contents and $\mathrm{Pb}$ isotope tracing technique.

\section{EXPERIMENTAL}

Field sampling for surface sediments $(<5 \mathrm{~cm})$ was conducted in August 2008. The sampling stations in western Xiamen Bay and the Jiulong River Estuary are shown in Fig. 1. Stns 1-14 and Stns 15-27 were located in the Jiulong River Estuary and western Xiamen Bay, respectively. Eight samples of suspended particle matters (SPM) were collected by 0.45 $\mu \mathrm{m}$ filtration film. Following the field work, small stones and conch debris in sediment samples were removed by hand and particle-size fractions of sediment samples were isolated using $63 \mu \mathrm{m}$ nylon mesh, got the $<63 \mu \mathrm{m}$ fraction of sediment samples. The dried samples were then ground to a powder 


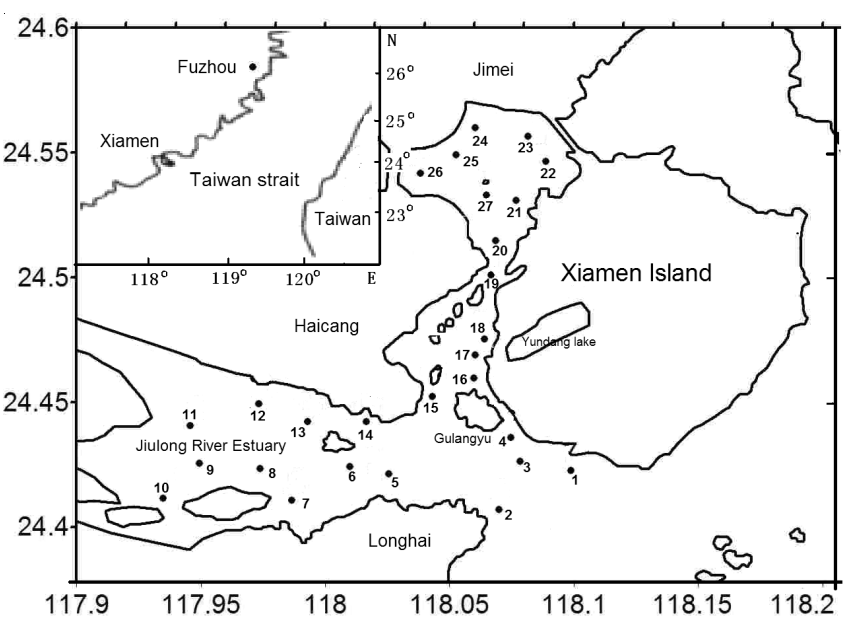

Fig. 1. Sampling stations in western Xiamen Bay and the Jiulong River Estuary

with a mortar and pestle, sieved through a 250 mesh sieve and kept in pre-cleaned containers for future use. The filtration film samples were dried at $40^{\circ} \mathrm{C}$ and also kept in pre-cleaned containers for future use.

Metal and lead isotopic analysis: Duplicate sediment samples were analyzed for metal content using $\mathrm{HCl}-\mathrm{HNO}_{3}-$ $\mathrm{HF}-\mathrm{HClO}_{4}$ mixture digestion. Suspended particle matters were digested as sediment samples for lead isotopic analysis. Precision and accuracy were verified using standard reference materials from the National Research Center for Geoanalysis, China (GSD-1 and GSD-4 sediment). Differences in metal concentrations between this study and the certified values were generally $<10 \%$. The water used for dilution and dissolution was purified using a Millipore deionizing system at $18.2 \mathrm{M} \Omega$. $\mathrm{HCl}, \mathrm{HF}, \mathrm{HClO}_{4}$ and $\mathrm{HNO}_{3}$ were bought directly as ultra-pure reagents. Solutions from digested sediments were stored in $25 \mathrm{~mL}$ high density polyethylene sample bottles at $4{ }^{\circ} \mathrm{C}$ until analysis. Lead and $\mathrm{Al}$ were measured using a Perkin-Elmer ICP-OES SCIEX Optima5300DV.

Lead isotopic analyses were carried out using a PerkinElmer ICP-QMS SCIEX Elan 9000 as described in the literatures $^{11-13}$. Precision and accuracy were verified using a standard reference material from the National Institute of Standards and Technology (SRM 981 common lead isotopic material). Repeated measurements of the SRM $981 \mathrm{~Pb}$ reference material over different analytical sessions yielded the following mass ratios: ${ }^{207} \mathrm{~Pb} /{ }^{206} \mathrm{~Pb}=0.913 \pm 0.004$ and ${ }^{208} \mathrm{~Pb} /{ }^{206} \mathrm{~Pb}=2.150 \pm$ 0.008. The standard accepted values are: ${ }^{207} \mathrm{~Pb} /{ }^{206} \mathrm{~Pb}=0.9146$ and ${ }^{208} \mathrm{~Pb} /{ }^{206} \mathrm{~Pb}=2.1681 . \mathrm{Pb}$ isotopic ratios reported in this work were calibrated using SRM 981 which was re-analyzed after every second sample.

\section{RESULTS AND DISCUSSION}

Lead contents in the surface sediments: Lead contents in the surface sediments from western Xiamen Bay and the Jiulong River Estuary are shown in Fig. 2. Lead contents ranged from $28.2-91.9 \mathrm{mg} \mathrm{kg}^{-1}$ with the mean 45.3 ( \pm 15.9 , std. deviation) $\mathrm{mg} \mathrm{kg}^{-1}$ in the surface sediments from the Jiulong River Estuary and the highest $\mathrm{Pb}$ content $\left(91.9 \mathrm{mg} \mathrm{kg}^{-1}\right)$ was found in the sampling site 14 (Fig. 2). Lead contents ranged from $33.1-84.6 \mathrm{mg} \mathrm{kg}^{-1}$ with the mean 48.4 ( \pm 15.8 , std. deviation $)$

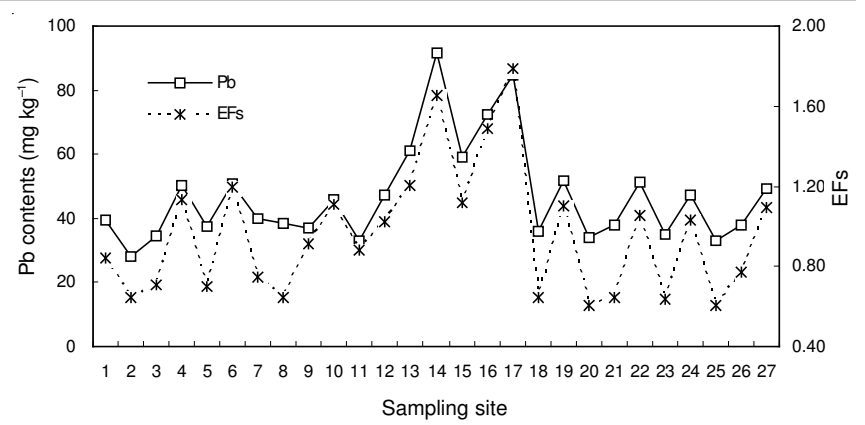

Fig. 2. Lead contents and enrichment factor values in the sediments from western Xiamen Bay and the Jiulong River Estuary

$\mathrm{mg} \mathrm{kg}^{-1}$ in the surface sediments from the western Xiamen Bay and the highest $\mathrm{Pb}$ content $\left(84.6 \mathrm{mg} \mathrm{kg}^{-1}\right)$ was found in the $16^{\text {th }}$ sampling site (Fig. 2). Fig. 2 also showed the spatial variations of $\mathrm{Pb}$ contents in sediments from different sampling sites. Fig. 2 also showed that $\mathrm{Pb}$ content in the sampling site 13-17 was obviously higher than them in the other sites. The sampling site 13-17 is around the Songyu coal burning power plant, located in Haicang (Fig. 1), which may release $\mathrm{Pb}$-bearing particulates into sediments through atmospheric deposition, wastewater and runoff.

Lead contents in the sediments from some literatures and the national standards for marine sediment quality, P.R. China were listed in Table-1. Table-1 shows that the lead contents in present study were consistent with them of the previous reports $^{8-10}$. Lead contents in Quanzhu Bay, locates next to Xiamen Bay, were higher than them of our study (Table- 1$)^{14}$. Lead contents in our study were also consistent with them in sediments from Peral River Estuary report by Wang et al. ${ }^{15}$ and higher than them in sediments from Yangtze river estuary report by An et al. ${ }^{16}$, in River Estuary and Bay in China (Table1). In generally, $\mathrm{Pb}$ contents in our study were higher than them in the reports ${ }^{17-19}$ and less than them in sediments from other researches ${ }^{20-23}$ in Table-1. Lead contents in our study were lower than the secondary standard of marine sediment quality, P.R. China ${ }^{24}$, suggesting no serious lead contamination in the studied region.

TABLE-1

LEAD CONTENTS $\left(\mathrm{mg} \mathrm{kg}^{-1}\right)$ IN THE SEDIMENTS IN THE STUDIED AREA WITH THOSE FROM SOME LITERATURES

\begin{tabular}{lcc}
\hline \multicolumn{1}{c}{ Region } & $\mathrm{Pb}$ & Ref. \\
\hline Western Xiamen Bay (China) & $46.8 \pm 15.6$ & This study \\
Western Xiamen Bay (China) & 50 & 8 \\
Western Xiamen Bay (China) & 52 & 9 \\
Western Xiamen Bay (China) & $21.4-114$ & 10 \\
Quanzhou Bay (China) & $105-242$ & 14 \\
Peral River Estuary (China) & 37.83 & 15 \\
Yangtze river estuary (China) & $21.9 \pm 4.1$ & 16 \\
Mandovi estuary(India) & $4.5-46.5$ & 17 \\
Mazatlán Harbor (Mexico) & $49.6-54.0$ & 18 \\
Lake Victoria (Tanzania) & $29.6 \pm 1.6$ & 19 \\
Kaohsiung Harbor (Taiwan) & $9.5-470$ & 20 \\
Keratsini Harbor (Greece) & $521-1263$ & 21 \\
Taranto Gulf (Italy) & 57.8 & 22 \\
Montevideo harbor (Uruguay) & $44-128$ & 23 \\
Primary standard & 60 & 24 \\
Secondary standard & 130 & 24 \\
Tertiary standard & 250 & 24 \\
\hline
\end{tabular}


In order to differentiate anthropogenic sources from natural origin of $\mathrm{Pb}$ in surface sediments, enrichment factor $(\mathrm{EF})$ was used for data analysis in the present study. The enrichment factor or lead were calculated using the follow equation:

$$
\text { Enrichment factor }(\mathrm{EF})=\frac{\left(\frac{\mathrm{C}_{\mathrm{Pb}}}{\mathrm{C}_{\mathrm{Al}}}\right)_{\text {Sample }}}{\left(\frac{\mathrm{C}_{\mathrm{Pb}}}{\mathrm{C}_{\mathrm{Al}}}\right)_{\text {Background }}}
$$

where $\left(\mathrm{C}_{\mathrm{Pb}} / \mathrm{C}_{\mathrm{Al}}\right)_{\text {sample }}$ is the ratio of $\mathrm{Pb}$ to $\mathrm{Al}$ in the samples and $\left(\mathrm{C}_{\mathrm{Pb}} / \mathrm{C}_{\mathrm{Al}}\right)_{\text {background }}$ is the natural background value of the ratio of $\mathrm{Pb}$ to $\mathrm{Al}^{25}$. The elemental contents in the local soil were used in this study as the background $\left(46.8 \mathrm{mg} \mathrm{kg}^{-1}\right.$ for $\mathrm{Pb}$ and 8.98 $\%$ for $\mathrm{Al})^{26}$. The enrichment factors ranged from 0.60 to 1.79 with the mean value of 0.96 . According to the enrichment factor categories based on the previous research ${ }^{25}$ : enrichment factor $<2$ means deficiency to minimal enrichment. Therefore, the enrichment of anthropogenic lead was not serious in the studied region.

Lead isotopic compositions in the surface sediments and the suspended particle matters: Lead isotopic compositions in the studied sediments and suspended particle matters were shown in Table-2 and Fig. 3. Table-2 shows that the range and mean $( \pm \mathrm{SD})$ values were 1.173-1.186 $(1.178 \pm 0.004)$ for ${ }^{206} \mathrm{~Pb} /{ }^{207} \mathrm{~Pb}$ and $2.078-2.101(2.090 \pm 0.007)$ for ${ }^{208} \mathrm{~Pb} /{ }^{206} \mathrm{~Pb}$, respectively. The relative deviations of the maximum and minimum value were less than $2 \%$ (Table-2), suggesting homogenization effect on $\mathrm{Pb}$ isotopic ratios from different sampling sites. It is consistent with the reported by Choi et al. ${ }^{6}$. The $\mathrm{Pb}$

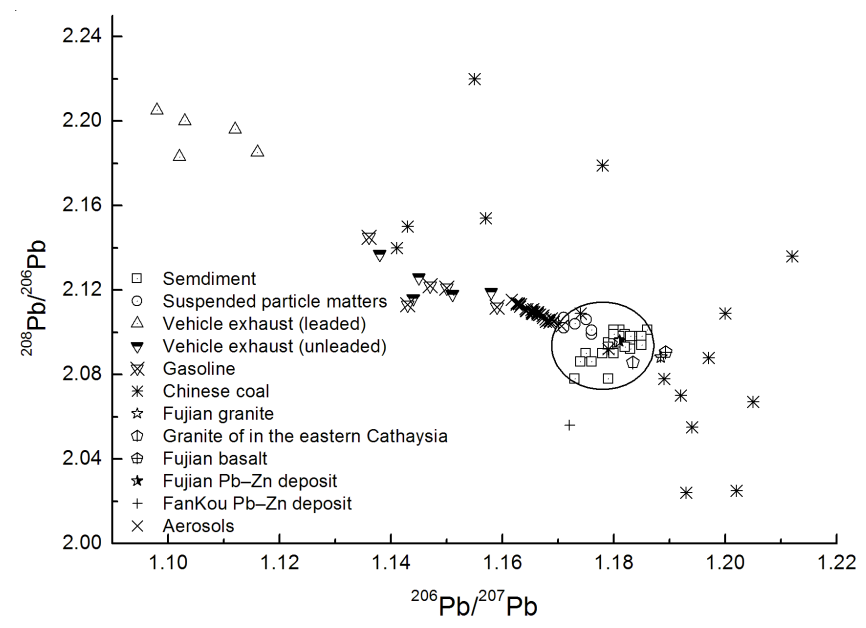

Fig. 3. Plot of ${ }^{206} \mathrm{~Pb} /{ }^{207} \mathrm{~Pb}$ vs. ${ }^{208} \mathrm{~Pb} /{ }^{206} \mathrm{~Pb}$. Sources data for vehicle exhaust (leaded/ unleaded) were from ${ }^{33,34}$; data for Chinese coal from ${ }^{34}$ and $(1993)^{36}$; data for Fujian granite and Fujian basalt from ${ }^{31}$; data for Granite of in the eastern Cathaysia and FanKou $\mathrm{Pb}-\mathrm{Zn}$ deposit from $^{32}$; data for Fujian $\mathrm{Pb}-\mathrm{Zn}$ deposit from ${ }^{28}$ and data for aerosols from $^{27}$

isotope ratios in the suspended particle matters ranged from 1.171-1.176 for ${ }^{206} \mathrm{~Pb} /{ }^{207} \mathrm{~Pb}$ and from $2.099-2.107$ for ${ }^{208} \mathrm{~Pb} /$ ${ }^{206} \mathrm{~Pb}$, indicating the difference of $\mathrm{Pb}$ sources between sediments and suspended particle matters.

Source identification using lead isotopic compositions: The $\mathrm{Pb}$ isotopic ratios $\left({ }^{206} \mathrm{~Pb} /{ }^{207} \mathrm{~Pb}\right.$ and $\left.{ }^{208} \mathrm{~Pb} /{ }^{206} \mathrm{~Pb}\right)$ in the potential natural sources in the literatures are also shown in Table-2 and Fig. 3. The $\mathrm{Pb}$ isotopic ratios $\left({ }^{206} \mathrm{~Pb} /{ }^{207} \mathrm{~Pb}\right.$ and ${ }^{208} \mathrm{~Pb} /$ ${ }^{206} \mathrm{~Pb}$ ) in the studied sediments were different from them in aerosols in Xiamen, which had a slight low ratios of ${ }^{206} \mathrm{~Pb} /$

TABLE-2

$\mathrm{Pb}$ ISOTOPIC COMPOSITIONS OF NATURAL BACKGROUND AND POLLUTION SOURCES

\begin{tabular}{|c|c|c|c|}
\hline & ${ }^{206} \mathrm{~Pb} /{ }^{207} \mathrm{~Pb}$ & ${ }^{208} \mathrm{~Pb} /{ }^{206} \mathrm{~Pb}$ & Ref. \\
\hline Sediment & $1.173-1.186(1.181 \pm 0.003)$ & $2.078-2.101(2.094 \pm 0.006)$ & This study \\
\hline SPM & $1.171-1.176(1.173 \pm 0.002)$ & $2.099-2.107(2.104 \pm 0.003)$ & This study \\
\hline Aerosols & $1.17058-1.16166(1.16595)$ & $2.10285-2.11544(2.10897)$ & 27 \\
\hline \multicolumn{4}{|c|}{ Natural sources } \\
\hline Fujian granite & 1.1884 & 2.0882 & 31 \\
\hline Fujian basalt & 1.1893 & 2.0905 & 31 \\
\hline Granite of in the eastern Cathaysia & 1.1834 & 2.0856 & 32 \\
\hline Uncontaminated soil & 1.1952 & 2.0763 & 32 \\
\hline Granite in the Pearl River Delta & 1.1842 & 2.0963 & 32 \\
\hline Volcanic rocks in Foshan & 1.1993 & 2.0816 & 32 \\
\hline \multicolumn{4}{|c|}{ Anthropogenic sources } \\
\hline Fujian $\mathrm{Pb}-\mathrm{Zn}$ deposit & $1.182-1.180(1.181)$ & $2.0921-2.0996(2.0958)$ & 28 \\
\hline Fankou $\mathrm{Pb}-\mathrm{Zn}$ deposits & 1.172 & 2.110 & 32 \\
\hline Vehicle exhaust(leaded gasoline) & $1.098-1.112(1.106)$ & $2.183-2.205(2.194)$ & 33 \\
\hline Vehicle exhaust(unleaded gasoline) & $1.138-1.158(1.147)$ & $2.116-2.137(2.123)$ & 33 \\
\hline Gasoline & $1.143-1.159(1.150)$ & $2.112-2.121(2.115)$ & 33 \\
\hline vehicle exhaust & $1.118-1.143(1.130)$ & $2.141-2.151(2.146)$ & 34 \\
\hline vehicle exhaust(leaded) in Shanghai & 1.110 & 2.194 & 35 \\
\hline vehicle exhaust(unleaded) in Shanghai & 1.147 & 2.124 & 35 \\
\hline vehicle exhaust in the pearl river delta & 1.160 & 2.085 & 23 \\
\hline Chinese coal & $2.024-2.154(2.089)$ & $1.141-1.205(1.182)$ & 36 \\
\hline Coal in Shanghai $(\mathrm{n}=23)$ & $1.208-1.140(1.163)$ & 2.1111 & 33 \\
\hline Coal combustion dust in Shanghai & $1.172-1.163(1.167)$ & - & 33 \\
\hline Coal fly ash in Shanghai $(\mathrm{n}=3)$ & $1.170-1.161(1.166)$ & - & 33 \\
\hline Coal combustion in Shanghai & 1.1633 & 2.1111 & 35 \\
\hline Unburned coal & $1.15-1.212(1.181)$ & $2.092-2.220(2.157)$ & 34 \\
\hline Metallurgic dust in Shanghai & 1.1725 & 2.0768 & 35 \\
\hline
\end{tabular}


${ }^{207} \mathrm{~Pb}$ and high ratios of ${ }^{208} \mathrm{~Pb} /{ }^{206} \mathrm{~Pb}^{27}$. The $\mathrm{Pb}$ isotopic ratios of suspended particle matters overlapped with aerosols and sediments (Fig. 3). The $\mathrm{Pb}$ isotopic ratios in the studied sediments lapped over them in granite of in the eastern Cathaysia and were closer to them from Fujian granite and Fujian basalts (Fig. 3). Therefore, Fujian basalts and granite might be the important potential natural sources.

Generally, industrial emissions, vehicle exhausts and coal combustion are the three major lead pollution sources in Chinese cities ${ }^{2}$. Therefore, the isotope ratios of the potential sources of anthropogenic $\mathrm{Pb}$ in literatures are also presented in Fig. 3. Fig. 3 shows that the $\mathrm{Pb}$ isotope ratios in the present study were consistent with them from Fujian $\mathrm{Pb}-\mathrm{Zn}$ deposit and different from those in FanKou Pb-Zn deposit (Fig. 3). Gasoline and vehicular $\mathrm{Pb}$ were the most important $\mathrm{Pb}$ contamination sources for atmospheric particles during the period of the use of leaded petrol. Fig. 3 shows that $\mathrm{Pb}$ isotope ratios in the present study were different from those in oil combustion and vehicle exhaust (unleaded/leaded gasoline), which had lower ${ }^{206} \mathrm{~Pb} /{ }^{207} \mathrm{~Pb}$ ratios. After the ban of leaded gasoline, vehicle exhaust is not a significant anthropogenic $\mathrm{Pb}$ source ${ }^{28}$. $3.45 \times 10^{6}$ ton coal and $3.44 \times 10^{6}$ ton coal were used as industrial raw material and fuel coal in thermal power industry in 2006 in Xiamen, respectively ${ }^{29}$, so coal is still the most important onetime energy in Xiamen. The combustion of coal releases harmful particulates, including $\mathrm{Pb}$-bearing particulates, into the environment. For example, Songyu coal burning power plant locates in western Xiamen Bay, which may release $\mathrm{Pb}$-bearing particulates into western Xiamen Bay and Jiulong River Estuary through atmospheric deposition, wastewater and runoff. Mukai et al. ${ }^{30}$ reported that Chinese coal has wide variations in lead isotopic ratios. Fig. 3 shows that the $\mathrm{Pb}$ isotopic ratios in the studied sediments were in range of the $\mathrm{Pb}$ isotopic ratios in the Chinese coal. It can be speculated that the consumption of coal might play an important role in $\mathrm{Pb}$ accumulation in the studied sediments. Based on the $\mathrm{Pb}$ isotopic ratios, the $\mathrm{Pb}$ that accumulates in the sediments is a mixture of $\mathrm{Pb}$ derived from natural sources and anthropogenic sources (coal combustion, industrial emissions and others) and gasoline and vehicular $\mathrm{Pb}$ were not the primary sources of $\mathrm{Pb}$ contamination for the sediments.

\section{ACKNOWLEDGEMENTS}

The authors would like to thank Ms Lizhen Lin, a research assistant, Ms Liping Zheng, Mr Yuyuan Xie, Mr Lei Wang and Mr Jianbin Liu, graduate students at Xiamen University, for their assistance in the sampling work. The work was supported by National Natural Science Fund of China (21007026), Fundamental Research Funds for the Central Universities and the Open Fund of Center of Material Analysis, Nanjing University.

\section{REFERENCES}

1. US Geological Survey, http://minerals.usgs.gov/minerals/pubs/commodity/lead/ (2009).
2. H. Cheng and Y. Hu, Environ. Pollut., 158, 1134 (2010).

3. B. Gulson, M. Korsch, W. Winchester, M. Devenish, T. Hobbs, C. Main, G. Smith, K. Rosman, L. Howearth, L. Burn-Nunes, J. Seow, C. Oxford, G. Yun, L. Gillam and M. Crisp, Environ. Res., 112, 100 (2012).

4. M. Komárek, V. Ettler, V. Chrastný and M. Mihaljevic, Environ. Int., 34, 562 (2008).

5. Y. Bentahila, D.B. Othman and J.M. Chemical, Geology, 248, 62 (2008).

6. M.S. Choi, H.I. Yi, S.Y. Yang, C.B. Lee and H.J. Cha, Marine Chem., 107, 255 (2007).

7. I. Renberg, M.L. Brannvall, R. Bindler and O. Emteryd, Sci. Total Environ., 292, 45 (2002).

8. L. Zhang, X. Ye, H. Feng, Y. Jing, T. Ouyang, X. Yu, R. Liang, C. Gao and W. Chen, Marine Pollut. Bull., 54, 974 (2007).

9. C. Yan, Q. Li, X. Zhang and G. Li, Environ. Earth Sci., 60, 1469 (2010).

10. G. Li, Z. Cao, D. Lan, J. Xu, S. Wang and W. Yin, Environ. Geol., 52, 1559 (2007).

11. C.R. Quétel, B. Thomas, O.F.X. Donard and F.E. Grousset, Spectrochim. Acta B, 52, 177 (1997).

12. J.M. Godoy, M.L.D.P. Godoya and C.C. Aronne, J. Braz. Chem. Soc., 18, 969 (2007).

13. M.L. Brännvall, H. Kurkkio, R. Bindler, O. Emteryd and I. Renberg, Environ. Geol., 40, 1057 (2001).

14. R. Yu, X. Yuan, Y. Zhao, G. Hu and X. Tu, J. Environ. Sci., 20, 664 (2008).

15. S. Wang, Z. Cao, D. Lan, Z. Zheng and G. Li, Environ. Geol., 55, 963 (2008).

16. Q. An, Y. Wu, J. Wang and Z. Li, Environ. Earth Sci., 59, 363 (2009).

17. R. Alagarsamy, Estuarine Coastal Shelf Sci., 67, 333 (2006).

18. M. Jara-Marini, M. Soto-Jiménez and F. Páez-Osuna, Bull. Environ. Contam. Toxicol., 80, 150 (2008).

19. M.A. Kishe and J.F. Machiwa, Environ. Int., 28, 619 (2003).

20. C.W. Chen, C.M. Kao, C.F. Chen and C.D. Dong, Chemosphere, 66, 1431 (2007).

21. S. Galanopoulou, A. Vgenopoulos and N. Conispoliatis, Water Air Soil Pollut., 202, 121 (2009)

22. A. Buccolieri, G. Buccolieri, N. Cardellicchio, A. Dell'Atti, A.Di Leo and A. Maci, Marine Chem., 99, 227 (2006).

23. P. Muniz, E. Danula, B. Yannicelli, J. Garcia-Alonso, G. Medina and M.C. Bicego, Environ. Int., 29, 1019 (2004).

24. CSBTS (China State Bureau of Quality and Technical Supervision), The People's Republic of China National Standards GB, pp. 186682002, Marine Sediment Quality (2002).

25. J. Zhang and C.L. Liu, Estuarine Coastal Shelf Sci., 54, 1051 (2002).

26. Environmental Monitoring of China, Background Values of Elements in Chinese soil (In Chinese), Beijing, China Environmental Sciences Press (1990).

27. L. Zhu, J. Tang, B. Lee, Y. Zhang and F. Zhang, Marine Pollut. Bull., 60, 1946 (2010).

28. J. Chen, M. Tan, Y. Li, Y. Zhang, W. Lu, Y. Tong and J. Zhang, Atmos. Environ., 39, 1245 (2005)

29. XMEPA (Xiamen Environmental Protection Bureau), Xiamen Environment Quality Communique (2006), http://www.xmepb.gov.cn/sj/ ContentView.aspx?CmsList=102\&CmsID=12 (2007).

30. H. Mukai, A.Tanaka, T. Fujii, Y.Q. Zeng, Y.T. Hong, J. Tang, S. Guo, H.S. Xue, Z.L. Sun, J.T. Zhou, D.M.Xue, J. Zhao, G.H. Zhai, J.L. Gu and P.Y. Zhai, Environ. Sci. Technol., 35, 1064 (2001).

31. B.Q. Zhu, J. Geochem. Explor, 55, 171 (1995).

32. B.Q. Zhu, Y.W. Chen and J.H. Peng, Appl. Geochem., 16, 409 (2001).

33. Y.H. Jiang, H.N. Chen, Q.H. Wu and S.Y. Chen, Fujian Geological Explor., 32, 16 (1996) (in Chinese with English Abstract).

34. J. Zheng, M.G. Tan, Y. Shibata, A. Tanaka, Y. Li, G.L. Zhang, Y. Zhang and Z. Shan, Atmos. Environ., 38, 1191 (2004).

35. M.G. Tan, G.L. Zhang, X.L. Li, Y.X. Zhang, W.S. Yue, J.M. Chen, Y.S. Wang, A.G. Li, Y. Li, Y.M. Zhang and Z.C. Shan, Anal. Chem., 78, 8044 (2006).

36. H. Mukai, N. Furuta, T. Fuji, Y. Ambe, K. Sakamoto and Y. Hashimoto, Environ. Sci. Technol., 27, 1347 (1993). 